\title{
TWO-REGION REACTIVITY WORTH METHOD FOR ANALYSIS OF FUEL-POISON SUBASSEMBLIES
}

NOVEMBER 1959

CONTRACT AT-11-1-GEN-14

BETTIS ATOMIC POWER LABORATORY, PITTSBURGH, PA., OPERATED FOR THE U.S. ATOMIC ENERGY COMMISSION BY WESTINGHOUSE ELECTRIC CORPORATION 


\section{DISCLAIMER}

This report was prepared as an account of work sponsored by an agency of the United States Government. Neither the United States Government nor any agency Thereof, nor any of their employees, makes any warranty, express or implied, or assumes any legal liability or responsibility for the accuracy, completeness, or usefulness of any information, apparatus, product, or process disclosed, or represents that its use would not infringe privately owned rights. Reference herein to any specific commercial product, process, or service by trade name, trademark, manufacturer, or otherwise does not necessarily constitute or imply its endorsement, recommendation, or favoring by the United States Government or any agency thereof. The views and opinions of authors expressed herein do not necessarily state or reflect those of the United States Government or any agency thereof. 


\section{DISCLAIMER}

Portions of this document may be illegible in electronic image products. Images are produced from the best available original document. 
UC-34: Physics and Mathematics

TID-4500 (15th Ed.)

\title{
TWO-REGION REACTIVITY WORTH METHOD FOR ANALYSIS OF FUEL-POISON SUBASSEMBLIES
}

\author{
J. C. Case
}

November 1959

Contract AT-11-1-GEN-14

Price $\$ .50$

Available from the Office of Technical Services,

Department of Commerce,

Washington 25, D. C.

\section{NOTE}

This document is an interim memorandum prepared primarily for internal reference and does not represent a final expression of the opinion of Westinghouse. When this memorandum is distributed externally, it is with the express understanding that Westinghouse makes no representation as to completeness, accuracy, or usability of information contained therein.

BETTIS ATOMIC POWER LABBORATORY

PITTSBURGH, PENNSYLVANIA

OPERATED FOR THE U.S. ATOMIC ENERGY COMMISSION BY

WESTINGHOUSE ELECTRIC CORPORATION 


\section{SPECIAL EXTERNAL DISTRIBUTION}

Manager; Pittsburgh Naval Reactors Operations Office, AEC

Babcock and Wilcox Co., L. G. Barrett

Westinghouse Air Arm Division, W. R. Morrís

University of Wisconsin, R. A. Ragatz

Westinghouse Radiation and Nucleonics Laboratories, S. L. Ruby

Republic Aviation Corp. . T. E. Stephenson

Belgonucleaire, Bruxelles, Belgium, G. C. Tavernier

Pcnnsylvania State College, C. S. Young

Fairleigh Dickinson University, C. Zucker

This report was prepared as an account of Government sponsored work. Neither the United States, nor the Commission, nor any person acting on hehalf of the Commission:

A. Makes any warranty or representation, expressed or implied, with respect to the accuracy, completeness, or usefulness of the information contained in this report, or that the use of any information, apparatus, method, or process disclosed in this report may not infringe privately owned rights; or

B. Assumes any liabilities with respect to the use of, or for damages resulting frnm the use of any information, apparatus, method, or process disclosed in this report.

As used in the above, "person acting on behalf of the Commission" includes any employe or contractor of the Commission, or employe of such contractor, to the extent that such employe or contractor of the commission, or employe of such contractor prcparcs, oisseminates, or provides access to, any information pursuant to his employment or contract with the Commission, or his emoloyment with such contractor. 


\section{CONTENTS}

Page No.

I. INTRODUCTION

1

II. DISCUSSION

1

III. PROBLEM SOLUTION

2

IV. ACCURACY OF RESULTS, ESTIMATE OF ERROR

5

V. SUMMARY AND CONCLUSIONS

ACKNOWLEDGMENTS

7

REFERENCE 
In the early production of reactor cores, a final nondestructive method to insure proper loading of fuel-poison subassemblies was desired. Subsequent analytical studies, presented herein, indi. cate that two-region reactivity measurements, as obtained from a suitable critical facility. should determine subassembly load. ing to within $2 g$ uranium and 0.03 g boron. Increased confidence in fuel component assembly methods resulted in a decision to abandon use of this method and, as a result, it has never been put into practice at the Bettis Laboratory.

\title{
TWO-REGION REACTIVITY WORTH METHOD FOR ANALYSIS OF FUEL-POISON SUBASSEMBLIES
}

\author{
J. C. Case
}

\section{INTRODUCTION}

The uranium analysis for a group of fuel subassemblies containing no poison, such as those in the PWR core, was accurately determined by reactivity measurements in the Production Test Facility (PTF) reactor. However, for subassemblies containing both fuel and poison, the reactivity measurement is a measure of the combined effects of the fuel and poison, and separation of their individual reactivity contributions is not possible. This report presents a quality control method for analysis of fuel-poison type subassemblies.

In the method described in this report, the measured parameter is again reactivity. In this case, however, two independent reactivity measurements are made on each subassembly under conditions where the reactivity worths of its fuel and poison have been changed. 'This change accompanies changes in the neutron energy spectrum within the critical reactor, and is accomplished by appropriate reactor core modifications.

The reactivity worths of subassembly fuel and poison are sensitive to changes in the value of the thermal flux in the subassembly relative to the rest of the core, and to changes in the adjoint thermal and fast fluxes in the subassembly. Two methods of accomplishing these changes that have been evaluated are (1) increasing a water gap between the subassembly tested and the reactor core, and (2) filling the water channels of the subassembly with water instead of air. The reactivity worths of uranium, boron, and zirconium have been calculated on the IBM-704 computer for the ne utron conditions obtained by these methods. Sufficient differences in reactivity worth of uranium and boron were observed to permit fuel-poison quantitative analysis. Partial verification of these calculations has been made by experimental comparison with generally good agreement (Table I).

\section{DISCUSSION}

Determination of both uranium and boron by dual reactivity measurements is based on the simplified equations: 
and

$$
R_{1}=x_{1} B+y_{1} U
$$

$$
\mathrm{R}_{2}=\mathrm{x}_{2} \mathrm{~B}+\mathrm{y}_{2} \mathrm{U}
$$

where

$R_{1}=$ measured reactivity in the first energy region,

$R_{2}=$ measured reactivity in the second energy region,

$x_{1}=$ boron reactivity worth in the first energy region,

$x_{2}=$ boron reactivity worth in the second energy region,

$\mathrm{y}_{1}=$ uranium reactivity worth in the first energy region,

$\mathrm{y}_{2}=$ uranium reactivity worth in the second energy region,

$\mathrm{B}=$ boron mass, * and

$\mathrm{U}=$ uranium mass."

In these equations, the boron and uranium worths have been calculated (using the MUFT-4. SOFOCATE, and WANDA-3 codes on the IBM -704) and have been partially checked experimentally. Since the reactivity values are measured and the reactivity worths are known, the result is two equations with two unknowns, i.e., boron and uranium mass.

Additional factors affect these basic equations. Zirconium mass differs among subassemblies and causes a reactivity contribution; in addition, the reactivity worth of zirconium changes in the different energy regions. Corrections for these items are easily made since the zirconium mass of the subassembly is obtained by weighing the subassembly and subtracting from this the small nominal uranium and boron loadings, while zirconium worths are obtained by IBM calculations and experimental results in a manner similar to the determination of uranium and boron worths.

Another reactivity term is required when the water channels of the subassembly are filled with water. Changes in water channel volume, a function of over-all subassembly density, cause changes in the subassembly metal-to-water ratio, which in turn introduces a reactivity effect.

It has been pointed out that the reactivity measurement actually is the difference in reactivity between the particular tested subassembly and a standard subassembly (see Fig. 1). Hence, the calculated mass of boron and uranium will be the difference in loading between the tested subassembly and the standard. To obtain the total loading of the tested subassembly, it is necessary to add this mass difference to the total loading of the standard. Obviously, the accurate uranium, boron, and zirconium content of the standard must be known in order to expect accurate results for the other tested subassemblies.

A method was devised to obtain a more accurate standard. An "average" standard was developed by averaging the chemically reported boron and uranium content, the zirconium mass, and the reactivity for the entire group of measured subassemblies. Then, instead of comparing a test subassembly with a single standaid, it is compared with this average standard. The average standard has a much smaller uncertainty in mass values than any single subassembly and, for a large group of subassemblies, random error associated with chemical analysis of the standard is largely eliminated.

\section{PROBLEM SOLUTION}

The machine calculations were set up using subassembly loadings approximating those of two current designs and a reactor core equivalent to that of the Production Test Facility (PTF) reactor.

*This boron and uranium mass is actually the difference in loading between the tested subassembly and a standard, since the reactivity is measured relative to this standard. 


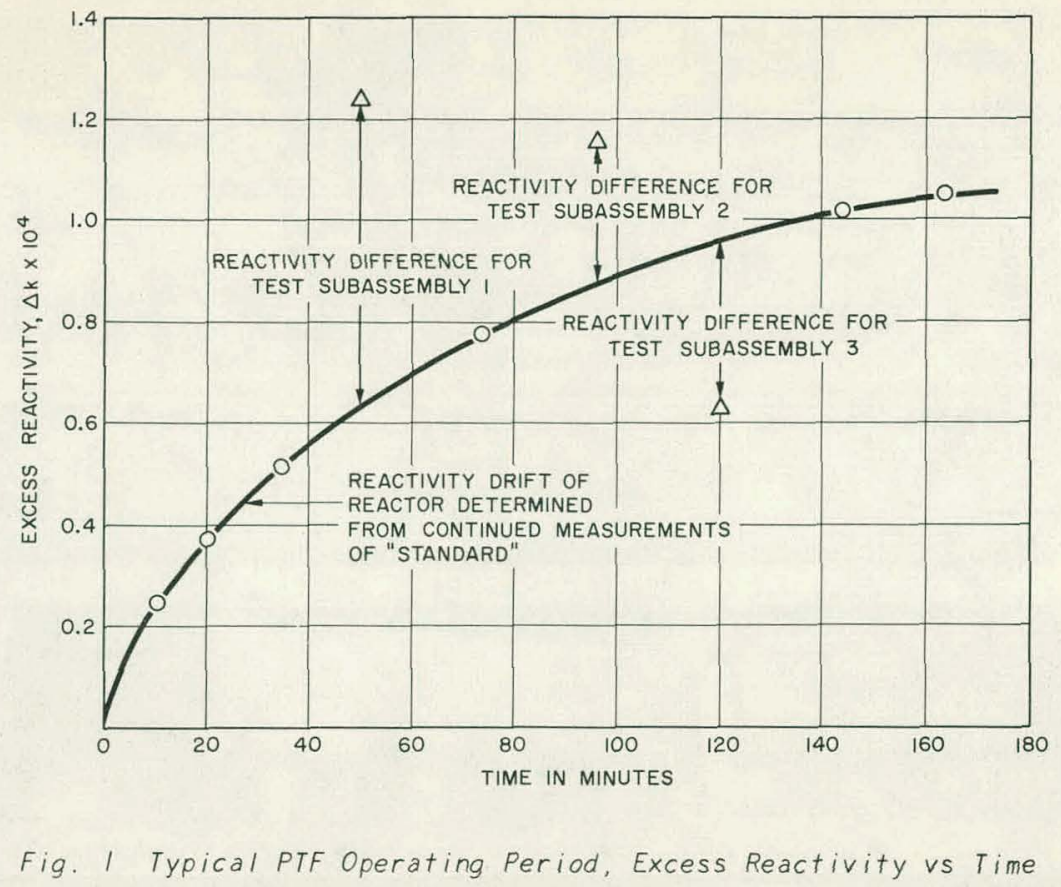

The Production Test Facility utilizes a low power, water-moderated reactor with a core of polyethylene-clad enriched uranium oxide fuel (Figs. 2 and 3). This fuel is contained in one-inch square aluminum tubes, so assembled as to form a box-shaped core, 58-in. long, 11-in. wide, and 14-in. high. A horizontal air hole passes through the center of this core to permit introduction of the subassemblies to be tested. For ease of calculation, this rectangular core was converted to a cylindrical core by conservation of area (Fig. 4). The cylindrical core consists of four concentric circular rings: the outer ring-the water reflector, the next ring-the fuel bearing core, the next ring-a small water gap, and the innermost ring-a cylinder corresponding to the test subassembly. These rings have outer radii of $27.79,17.79,6.80$, and $4.66 \mathrm{~cm}$, respectively.

Using the SOFOCATE and MUFT codes, slow and fast constants were calculated, and an eigenvalue near criticality was calculated with the WANDA code. Then, the uranium loading of the subassembly (inner ring) was reduced 10\%, new slow and fast constants were calculated, and a new eigenvalue determined. This change in eigenvalue represents the reactivity change resulting from the removal of an exact amount of uranium and, hence, gives the reactivity worth of the uranium for the change. The worths of boron and zirconium were calculated in a similar manner.

Next, the energy spectrum was changed by increasing the thickness of the inner water ring by about $6 \mathrm{~cm}$, resulting in new core radii of $32.11,22.11,12.90$, and $4.66 \mathrm{~cm}$, respectively. By using the MUFT, SOFOCATE, and WANDA codes as before, a series of new reactivity worths were calculated. Little change in boron worth was noted, but uranium worth increased about $50 \%$.

Finally, the energy spectrum was changed by filling the inner ring with water, so that the subassembly was surrounded by and filled with the water. Except for zirconium worth, calculations were made as before. For zirconium, however, it was necessary to take into account volume changes accompanying the large mass change. For example, a $10 \%$ increase in zirconium weight (1.9 kg) represents a volume increase of $300 \mathrm{cc}$ within the subassembly. This results in a $14.2 \%$ decrease in hydrogen and oxygen density which must be accounted for in the calculations. Boron worth changed from about 40 to $65 \%$ and uranium worth from about 65 to $100 \%$. Zirconium worth made a major change. A summary of these reactivity worths is presented in Table I. 


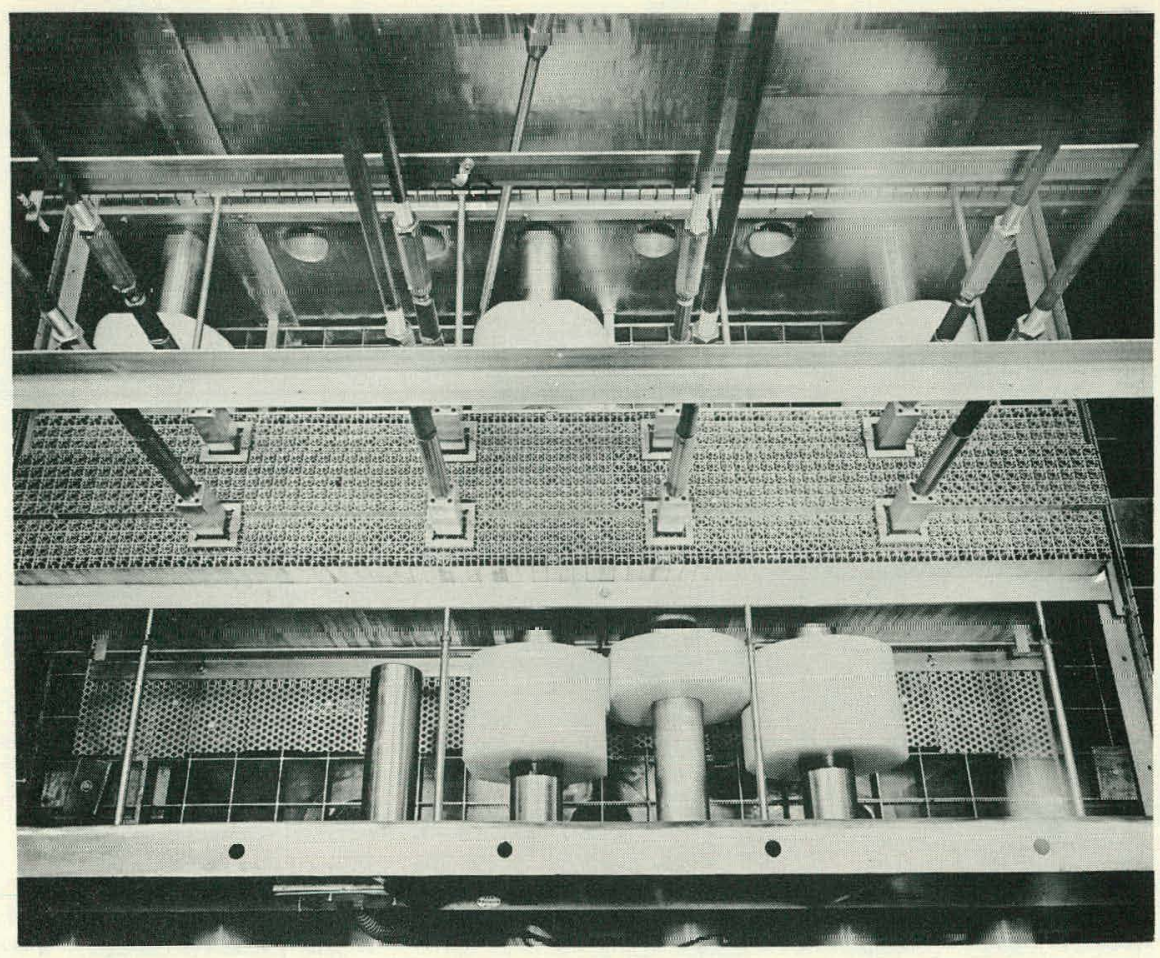

Fig. 2 Close-up View of PTF Reactor Core

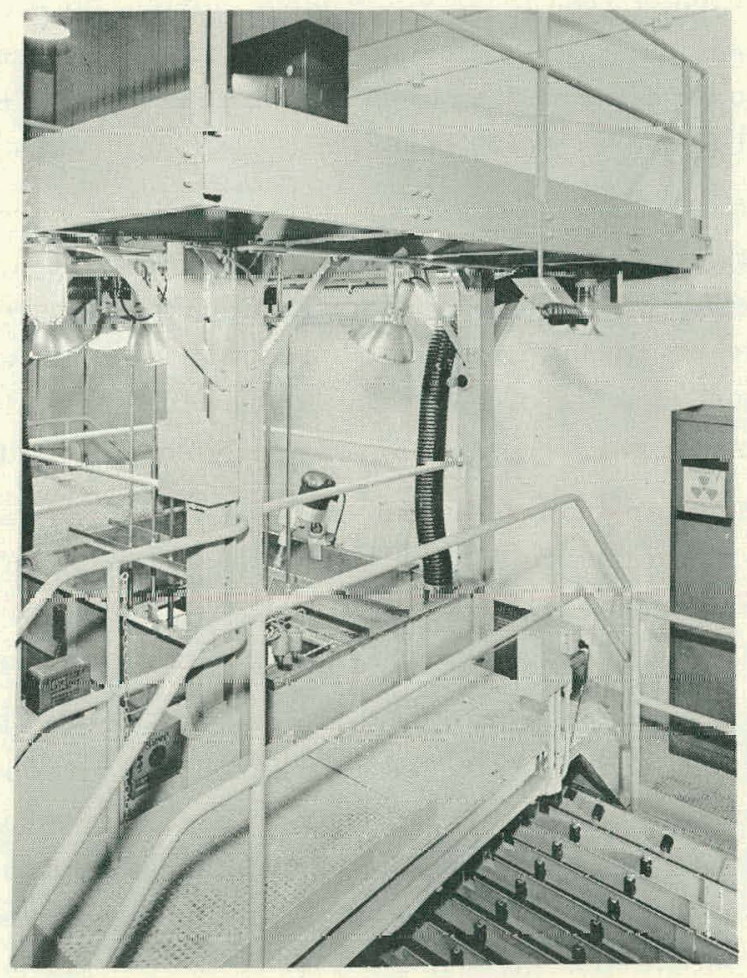

Fig. 3 View of PTF Reactor 


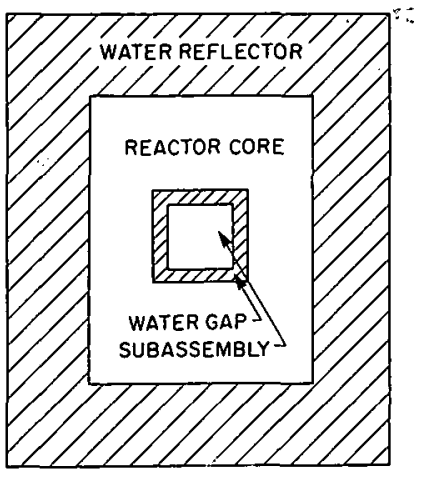

CROSS SECTION OF PTF CORE

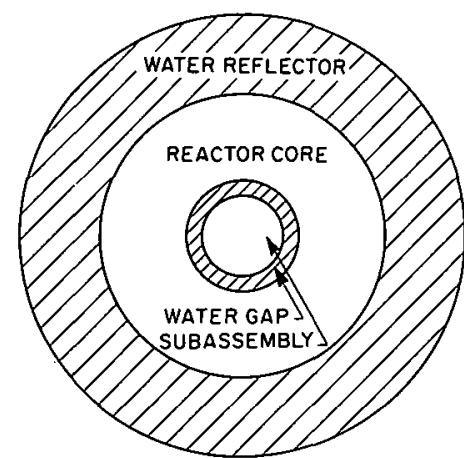

CROSS SECTION OF EQUIVALENT CYLINDRICAL CORE

Fig. 4 PIF Reactor Core and Equivalent Cylindrical Core

TABLE I

REACTIVITY WORTHS*

\begin{tabular}{|c|c|c|c|c|c|c|}
\hline \multirow[b]{2}{*}{ Subassembly } & \multicolumn{2}{|c|}{$\begin{array}{c}\text { Uranium } \\
(\Delta \mathrm{k} / \mathrm{g})\end{array}$} & \multicolumn{2}{|c|}{$\begin{array}{l}\text { Boron } \\
(\Delta \mathrm{k} / \mathrm{g})\end{array}$} & \multicolumn{2}{|c|}{$\begin{array}{c}\text { Zirconium } \\
(\Delta \mathrm{k} / \mathrm{kg})\end{array}$} \\
\hline & Calc Worth & Exp Worth & Calc Worth & Exp Worth & Calc Worth & Exp Worth \\
\hline \multicolumn{7}{|l|}{ Normal } \\
\hline Type I & +0.304 & +0.35 & -32.1 & -29.0 & +6.0 & +0.2 \\
\hline Type II & +0.310 & +0.34 & -25.6 & -20.2 & +10.8 & +0.8 \\
\hline \multicolumn{7}{|l|}{ Water Gap } \\
\hline Type I & +0.445 & -- & -32.0 & -- & +1.88 & -- \\
\hline \multicolumn{7}{|l|}{ Water Filled } \\
\hline Type I & +0.606 & -- & -53.0 & -- & -12.7 & $\cdots$ \\
\hline Type II & +0.471 & +0.45 & -44.6 & -22.6 & -11.5 & -8.6 \\
\hline
\end{tabular}

*Worth values are multiplied by $10^{4}$.

\section{ACCURACY OF RESULTS, ESTIMATE OF ERROR}

An estimation of the error associated with the variable water ring method of fuel-poison determination follows. For purposes of illustration, assume the differences in subassembly loadings are:

\begin{tabular}{|c|c|c|c|}
\hline & $\begin{array}{c}\text { Boron } \\
\text { (g) }\end{array}$ & $\begin{array}{l}\text { Uranium } \\
\text { (g) }\end{array}$ & $\underset{(\mathrm{kg})}{\text { Zir conium }}$ \\
\hline Test-standard & +0.20 & +10.0 & +0.5 \\
\hline
\end{tabular}

This particular difference in subassembly loading was chosen to conform to the greatest differences in loading (for a particular type of subassembly) encountered while reactivity testing about 250 subassemblies of six different types. Smaller differences in loading will have smaller errors associated with them. 
By experimental procedures (with reactivity represented by $\Delta \mathrm{k}$ ), the reactivity worth of boron, uranium, and zirconium can be determined as $\pm 0.5 \times 10^{-4} \Delta \mathrm{k} / \mathrm{g}, \pm 0.01 \times 10^{-4} \Delta \mathrm{k} / \mathrm{g}$, and $\pm 0.05 \times 10^{-4}$ $\Delta \mathrm{k} / \mathrm{kg}$, respectively $(95.45 \%$ confidence, 2 sigma value). However, the exact values of these worths, as determined by PTF, are affected by the distribution-of the boron, uranium, and zirconium within the subassembly; hence, wider confidence limits should be considered for suspected irregular subassembly loadings. Results of one such calculation based on uncertainty. limits four times greater are given later in this article. The calculated values of these worths are summarized in Table I, and the following representative values are used for this accuracy calculation:

$$
\begin{aligned}
& x_{1}=-32.0 \pm 0.5 \times 10^{-4} \Delta \mathrm{k} / g \text { (boron worth, region 1) } \\
& x_{2}=-32.0 \pm 0.5 \times 10^{-4} \Delta \mathrm{k} / g \text { (boron worth, region 2) } \\
& y_{1}=0.30 \pm 0.01 \times 10^{-4} \Delta \mathrm{k} / g \text { (uranium worth, region 1) } \\
& y_{2}=0.45 \pm 0.01 \times 10^{-4} \Delta \mathrm{k} / g \text { (uranium worth, region 2) }
\end{aligned}
$$

The two measured fuel-poison reactivities, corrected for zirconium difference, would then be

and

$$
R_{1}=10^{-4} \Delta \mathrm{k}(-32.0 \times 0.2+0.30 \times 10)=-3.4 \times 10^{-4} \Delta \mathrm{k}
$$

$$
\dot{R}_{2}=10^{-4} \Delta \mathrm{k}(-32.0 \times 0.2+0.45 \times 10)=-1.9 \times 10^{-4} \Delta \mathrm{k}
$$

For any particular reactivity measurement made with the PTF reactor, the accuracy of that measurement is $\pm 0.17 \times 10^{-4} \Delta \mathrm{k}(95.45 \%$ confidence, 2 sigma value $)$.

Solution of the basic reactivity equations gives

$$
\therefore \begin{array}{cc}
\because \cdots \\
\because n
\end{array} \quad B=\frac{y_{1} R_{2}-y_{2} R_{1}}{x_{2} y_{1}-x_{1} y_{2}}
$$

and

$$
\mathrm{U}=\frac{\mathrm{x}_{2} \mathrm{R}_{1}-\mathrm{x}_{1} \mathrm{R}_{2}}{\mathrm{x}_{2} \mathrm{y}_{1}-\mathrm{x}_{1} \mathrm{y}_{2}}
$$

An estimate of the variance in the boron determination was made using the partial differentation method described by Hald (Ref 1). [It is assumed that the variables of Eq (1) are statistically independent and the variance of the boron determination is linear in the range of the calculation.] Thus,

$$
\begin{array}{r}
\mathrm{v}_{\mathrm{B}}=\left(\frac{\partial \mathrm{B}}{\partial \mathrm{y}_{1}}\right)^{2}\left(\mathrm{u}_{\mathrm{y}_{1}}\right)^{2}+\left(\frac{\partial \mathrm{B}}{\partial \mathrm{y}_{2}}\right)^{2}\left(\sigma_{\mathrm{y}_{2}}\right)^{2}+\left(\frac{\partial \mathrm{B}}{\partial \mathrm{x}_{1}}\right)^{i}\left(\sigma_{\mathrm{x}_{1}}\right)^{2}+\left(\frac{\partial \mathrm{B}}{\partial \mathrm{x}_{2}}\right)^{2}\left(\sigma_{\mathrm{x}_{2}}\right)^{2} \\
+\left(\frac{\partial \mathrm{B}}{\partial \mathrm{R}_{1}}\right)^{2}\left(\sigma_{\mathrm{R}_{1}}\right)^{2}+\left(\frac{\partial \mathrm{B}}{\partial \mathrm{R}_{2}}\right)^{2}\left(\sigma_{\mathrm{R}_{2}}\right)^{2},
\end{array}
$$

whe re

$$
\begin{aligned}
& \frac{\partial \mathrm{B}}{\partial \mathrm{y}_{1}}=\frac{\left(\mathrm{x}_{2} \mathrm{y}_{1}-\mathrm{x}_{1} \mathrm{y}_{2}\right) \mathrm{R}_{2}-\left(\mathrm{y}_{1} \mathrm{R}_{2}-\mathrm{y}_{2} \mathrm{R}_{1}\right) \mathrm{x}_{2}}{\left(\mathrm{x}_{2} \mathrm{y}_{1}-\mathrm{x}_{1} \mathrm{y}_{2}\right)^{2}}=0.924, \\
& \frac{\partial \mathrm{B}}{\partial \mathrm{y}_{2}}=\frac{\left(\mathrm{x}_{2} \mathrm{y}_{1}-\mathrm{x}_{1} \mathrm{y}_{2}\right)\left(-\mathrm{R}_{1}\right)-\left(\mathrm{y}_{1} \mathrm{R}_{2}-\mathrm{y}_{2} \mathrm{R}_{1}\right)\left(-\mathrm{x}_{1}\right)}{\left(\mathrm{x}_{2} \mathrm{y}_{1}-\mathrm{x}_{1} \mathrm{y}_{2}\right)^{2}}=-0.614, \\
& \frac{\partial \mathrm{B}}{\partial \mathrm{x}_{1}}=\frac{-\left(\mathrm{y}_{1} \mathrm{R}_{2}-\mathrm{y}_{2} \mathrm{R}_{1}\right)\left(-\mathrm{y}_{2}\right)}{\left(\mathrm{x}_{2} \mathrm{y}_{1}-\mathrm{x}_{1} \mathrm{y}_{2}\right)^{2}}=0.0185,
\end{aligned}
$$




$$
\begin{aligned}
& \frac{\partial B}{\partial x_{2}}=\frac{-\left(y_{1} R_{2}-y_{2} R_{1}\right)\left(y_{1}\right)}{\left(x_{2} y_{1}-x_{1} y_{2}\right)^{2}}=-0.0124, \\
& \frac{\partial B}{\partial R_{1}}=\frac{-y_{2}}{x_{2} y_{1}-x_{1} y_{2}}=-0.093,
\end{aligned}
$$

and

$$
\frac{\partial \mathrm{B}}{\partial \mathrm{R}_{2}}=\frac{\mathrm{y}_{1}}{\mathrm{x}_{2} \mathrm{y}_{1}-\mathrm{x}_{1} \mathrm{y}_{2}}=0.062 .
$$

By solution for $V_{B}$, the variance for the boron determination was found to be 0.000152 and, from this, the standard deviation was $\pm 0.012 \mathrm{~g}$. The $2 \sigma$ (approximately $95 \%$ confidence) value for the boron determination is then $\pm 0.024 \mathrm{~g}$. In a similar manner, the variance of the uranium determination was calculated, yielding a $2 \sigma(95 \%$ confidence $)$ value for the uranium determination of $\pm 1.7 \mathrm{~g}$.

Thus, the results of this error estimation show the following uncertainty limits associated with this subassembly loading:

\begin{tabular}{lc} 
& \multicolumn{2}{c}{$\begin{array}{c}\text { Loading Difference } \\
\text { (g) }\end{array}$} \\
\cline { 2 - 2 } Uranium & $10 \pm 1.7$ \\
Boron & $0.20 \pm 0.024$
\end{tabular}

With smaller differences in loading between the standard and test subassembly, the uncertainty limits will decrease, reaching $\pm 0.6 \mathrm{~g}$ of uranium and $\pm 0.006 \mathrm{~g}$ of boron as a lower limit.

As indicated previously, wider confidence limits on reactivity worths should be considered for irregular subassembly loadings. New error limits of $\pm 2.5 \mathrm{~g}$ uranium and $\pm 0.066 \mathrm{~g}$ boron result from an increase (by the factor of 4 ) in the previously listed worth uncertainty limits.

\section{SUMMARY AND CONCLUSIONS}

The assurance that no improperly loaded fuel components are assembled into a nuclear reactor core is essential. Currently, assembly of reactor fuel components is based on chemical analysis of the parent ingot. Since analysis errors may occur, and since subsequent fabrication errors might take place, a final nondestructive analysis of completed fuel assemblies may be desired. The method discussed in this report shows promise of providing such control.

Calculations have indisated that accuracies within $2 \mathrm{~g}$ of uranium and $0.03 \mathrm{~g}$ of boron should be expected using the water-gap variation of the method discussed in this report. Variations in certain physical characteristics between subassemblies (such as metal-to-water ratio, channel spacing distribution of fuel and poison, and self shielding) tend to introduce additional reactivity effects into the actual uranium-boron analysis. It is desirable that these reactivity effects be identified for consideration in selection and assembly of core components.

Further experimental work would probably improve the accuracy obtainable from this method. For example, the optimum variation in water-gap thickness should be determined (only a $6-\mathrm{cm}$ change has been considered in this study). Modification of the reactor core to eliminate the water gap for one of the cases would probably increase the neutron energy spectrum change. The water moderation method appears to be an attractive means of fuel-poison analysis, since alteration of the fuel-bearing core would not be required; however, additional study is necessary to accurately evaluate reactivity effects of the metal-to-water ratio.

\section{ACKNOWLEDGMENTS}

The author wishes to express his appreciation to the many individuals who offered their assist ance during the course of the study and during the preparation of this report. Special thanks are due 
Mr. Edward Ney, who supervised the work; Mr. A. C. Nelson, Jr., who provided the method for preliminary error estimation; Mr. A. S. Covert, who provided the present form of error estimation; and to the staff of the PTF, for their assistance.

REFERENCE

1. A. Hald, Statistical Theory with Engineering Applications, (New York: J. Wiley \& Sons, 1952), p 118. 